\title{
Applicability of extracts from Centaurea calcitrapa in ripening of bovine cheese
}

\author{
Patrícia M. Reis ${ }^{\mathrm{a}}$, Pedro L. Lourenço ${ }^{\mathrm{b}}$, Ana Domingos ${ }^{\mathrm{b}}$, Alda F. Clemente, \\ M. Salomé Pais ${ }^{\mathrm{c}}$, F. Xavier Malcata ${ }^{\mathrm{a}, *}$ \\ ${ }^{a}$ Escola Superior de Biotecnologia, Universidade Católica Portuguesa, Rua Dr. Antonio Bernardino de Almeida, P-4200-072 Porto, Portugal \\ ${ }^{\mathrm{b}}$ Departamento de Biotecnologia, Instituto Nacional de Engenharia e Tecnologia Industrial, P-1649-038 Lisboa, Portugal \\ ${ }^{\circ}$ Centro de Biotecnologia Vegetal, Faculdade de Ciências da Universidade de Lisboa, P-1749-016 Lisboa, Portugal
}

\begin{abstract}
Aqueous extracts obtained from cell suspension cultures of Centaurea calcitrapa were used as proteolytic additive in the manufacture of a commercial bovine cheese, coagulated with animal rennet and typically ripened for $28 \mathrm{~d}$. The cheese was assessed in comparison to standard cheese for two levels of addition of said extract, viz. 0.61 and $1.22 \mathrm{mg}$ of total protein $\mathrm{mL}^{-1}$. The qualitative and quantitative evolutions of the nitrogen fractions were monitored in the experimental cheeses throughout the whole ripening period. In general, the chemical compositions of the cheeses were different depending on the amount of extract used, but no significant differences could be detected in the ripening index. With regard to electrophoretic profiles, the two types of cheese could be distinguished until up to ca. $7 \mathrm{~d}$ of ripening, but differences did essentially vanish by $28 \mathrm{~d}$. (C) 2001 Elsevier Science Ltd. All rights reserved.
\end{abstract}

Keywords: Cheese; Proteolysis; Plant enzymes

\section{Introduction}

Cheese produced via milk clotting brought about by enzymes of the stomach of recently slaughtered calves was inadvertently discovered in ancient times, and was ever since employed as a simple and efficient form of preservation of milk nutrients. A rennet suitable for cheese manufacture is characterized by a highly specific caseinolytic activity (i.e. the enzyme should promptly cleave the $\mathrm{Phe}_{105}-\mathrm{Met}_{106}$ bond in $\kappa$-casein) and a low general proteolytic activity (i.e. it should have a relatively low affinity toward other bonds in $\kappa-, \alpha_{\mathrm{s} 1}-$ and $\beta$-caseins) (Pires et al., 1994). In Portugal and bordering regions of Spain, rennets from plant origin, viz. crude aqueous extracts of flowers of the thistle (Cynara cardunculus, Cynara humilis and/or Cynara scolymus), have been used for centuries in the manufacture of raw ovine and/or caprine milk cheeses (Sá \& Barbosa, 1972). The milk clotting activity of the aforementioned extracts is due to

\footnotetext{
* Corresponding author. Tel.: 351-225580004; fax: 351-225090351.

E-mail address: xmalcata@esb.ucp.pt (F.X. Malcata).
}

proteases present therein; these enzymes were duly purified, and partially characterized in terms of activity (Heimgartner et al., 1990; Faro, 1991; Cordeiro, Jakob, Puhan, Pais, \& Brodelius, 1992) and specificity toward pure bovine caseins (Macedo, 1993). Other researchers (Domingos, Clemente, \& Pais, 1992a; Tavaria et al., 1997) have also shown the existence of proteinases with milk clotting activity in both the flowers and the leaves of Centaurea calcitrapa, a member of the native Portuguese flora, taxonomically included in the Compositae family and somewhat related to the genus Cynara (Quer, 1981; Franco, 1984).

This work attempted to deepen the previous characterization of extracts obtained from suspension cultures of C. calcitrapa (Domingos, Miguel, Clemente, \& Pais, 1992b) via assessing the applicability of distinct extract concentrations for actual cheesemaking. In order to monitor enzyme activities, physicochemical and biochemical characteristics were assayed in Castelões cheese (a semi-soft cheese with a pleasant flavour and clean taste, obtained from pasteurized standard cows' milk) throughout the regular ripening period, with a special emphasis on proteolysis. Proteolysis is indeed the most 
commonly used index of maturation because cheese caseins are converted, during ripening, into water-soluble nitrogenous compounds (viz. peptides and free amino acids), which contribute to flavour and texture of the final cheese (Fox, 1989).

\section{Materials and methods}

\subsection{Enzyme extraction}

The cell suspension culture of C. calcitrapa was duly established, as previously reported by Domingos et al. (1992b). Cells were homogenised at $4^{\circ} \mathrm{C}$ in a Waring Blender for 2 min using $50 \mathrm{mM}$ Tris- $\mathrm{HCl}$ buffer (pH 8.1) containing $1 \mathrm{mM}$ EDTA (ethylenediaminetetracetic acid) and $10 \%(\mathrm{w} / \mathrm{v})$ PVPP (polyvinylpolypyrrolidone). The homogenate was centrifuged at $11,000 \mathrm{~g}$ for $15 \mathrm{~min}$, and the supernatant was then lyophylised $\left(10^{-1}\right.$ mbar for $\left.2 \mathrm{~d}\right)$ and stored until use.

The milk clotting activity was measured on low-heat skim milk powder, Nilac (Nizo, Ede, The Netherlands), reconstituted by dissolving $12 \mathrm{~g}$ in $100 \mathrm{~mL}$ (final volume) of $10 \mathrm{mM} \mathrm{CaCl}_{2}(\mathrm{pH} 6.5)$ at $30^{\circ} \mathrm{C}$; the enzyme extracts were added at the ratio of $50 \mu \mathrm{L}$ per milliliter of reconstituted skim milk.

The protein content was measured by Bradford's method (Bradford, 1976). The enzyme activity was quantified as described elsewhere (Twining, 1984), using fluorescein isothiocyanate-casein (FITC) as substrate.

\subsection{Cheesemaking}

Bovine milk, previously pasteurized at $74^{\circ} \mathrm{C}$ for $15 \mathrm{~s}$, was divided into three batches, and each batch was used to manufacture 8 cheeses. Cheesemaking followed the standard industrial protocol for Castelões cheese, and took place in the industrial plant of Lactogal (Avis, Portugal): the milk was heated to $30^{\circ} \mathrm{C}$, added with $\mathrm{CaCl}_{2}$ at $0.2 \mathrm{~g} \mathrm{~L}^{-1}, \mathrm{KNO}_{3}$ at $0.2 \mathrm{~g} \mathrm{~L}^{-1}$ and commercial starter Flora Danica (Chr. Hansen's Lab, Hørsholm, Denmark) at $10^{7} \mathrm{CFU} \mathrm{mL}^{-1}$. After incubation for 30 min, chymosin (Maxiren ${ }^{\circledR}$, from Gist-Brocades, Seclin, France) was added as rennet; 8 cheeses were manufactured without further additives (Castelões cheese type, denoted hereafter as a), 8 cheeses were produced with the C. calcitrapa extract at $0.61 \mathrm{mg}$ total protein $\mathrm{mL}^{-1}$ (denoted hereafter as $b$ ), and 8 cheeses were produced with that extract at $1.22 \mathrm{mg}$ protein $\mathrm{mL}^{-1}$ (denoted hereafter as c). After $45 \mathrm{~min}$, the coagulum was cut, stirred and washed with chlorine-free water so as to reduce the acidity of the curd. The curd pieces were than assembled into cylindrical molds and mechanically pressed for $4 \mathrm{~h}$. The cheeses were salted in brine vats set at $18-20^{\circ}$ Baumé, at $10^{\circ} \mathrm{C} ; 4 \mathrm{~h}$ later, they were placed in a ripening room at $10^{\circ} \mathrm{C}$ and $82 \%$ relative humidity. Two cheeses from each batch were taken randomly at $0,7,14$ and $28 \mathrm{~d}$ of ripening, and the average of every set of replicated analytical determinations for each set of two cheeses was considered as a datum point.

\subsection{Chemical analysis}

The total solids (TS) content was determined via drying at $160^{\circ} \mathrm{C}$ for $13 \mathrm{~min}$ in an oven (Mettler Toledo, Greifensee, Switzerland). The $\mathrm{NaCl}$ content was determined by the modified Volhard method, using silver nitrate and potassium thiocyanate (Merck, Darmstadt, Germany) as described by Kosikowski (1982). The pH was measured by directly probing the cheese with a glass electrode connected to a potentiometer (Consort P107, Turnhout, Belgium). The fat content was determined by van Gulik's method (Anon., 1975) using 40\% (v/v) sulfuric acid (PronaLab, Lisbon, Portugal). The total nitrogen (TN) content was determined by the micro-Kjeldahl method, using a Kjeltec system 1002 Distilling unit (Tecator, Höganäs, Sweden). All determinations were made in duplicate.

\subsection{Biochemical analysis}

Water-soluble nitrogen (WSN) was obtained via fractionation of the cheese sample with water according to Kuchroo and Fox (1982). The trichloroacetic acid (TCA)-soluble extract (TCASN) was prepared by adding $y \mathrm{ml}$ of $48 \%(\mathrm{w} / \mathrm{v}) \mathrm{TCA}$ to $4 y \mathrm{~mL}$ of WSN; the mixture was allowed to stand for $30 \mathrm{~min}$ at room temperature, and then filtered through Whatman no. 542 filter paper (Maidstone, UK). The phosphotungstic (PTA)-soluble extract (PTASN) was prepared by adding $14.0 \mathrm{~mL}$ of $3.95 \mathrm{M}$ sulfuric acid (PronaLab) and $6 \mathrm{~mL}$ of $33.3 \%(\mathrm{w} / \mathrm{v})$ PTA to $20 \mathrm{~mL}$ of WSN; the mixture was allowed to stand overnight at $4{ }^{\circ} \mathrm{C}$ and subsequently filtered through Whatman no. 542 filter paper. Aliquots from WSN, TCASN and PTASN (5 mL) were then subject to the micro-Kjeldahl method. The ripening extension index, represented by the ratio WSN/TN (which is a measure of proteolytic activity), the ripening depth index, represented by the ratio TCASN/TN (Furtado \& Partridge, 1988), and the free amino acid index, represented by the ratio PTASN/TN (which reflects the aminopeptidase activities of the starter bacteria in cheese) (Aston, Durward, \& Dulley, 1983) were calculated from the experimental data. The degradation of casein was assayed in cheese samples by urea-polyacrylamide gel electrophoresis (PAGE) $(12.5 \% \mathrm{C}, 4 \% \mathrm{~T}$; $\mathrm{pH} 8.9)$ as well as on watersoluble and -insoluble extracts, using a Protean II XI vertical slab-gel unit (Bio-Rad Laboratories, Watford, UK) and the stacking gel system of Andrews (1983), with the modifications introduced by Shalabi and Fox (1987); the gels were stained with Coomassie blue G-250 (BioRad, Richmond CA, USA) using the method of Blakesley 
and Boezi (1977). Quantitation of intact $\beta$ - and $\alpha_{\mathrm{s} 1}$ caseins was by densitometry in a model GS-700 Imaging densitometer (Bio-Rad, Hercules CA, USA) and used the Molecular Analyst $^{\mathrm{TM}}$ software (Bio-Rad). All electrophoretic determinations were made in duplicate.

\subsection{Sensorial analysis}

An organoleptic pannel was set up for assessment of the experimental cheeses. Four parameters assayed related to the appearance of cheese (i.e. form, rind, colour and texture), and used one-half of each cheese; other characteristics (flavour and aroma) were evaluated in portions of the remaining half of the cheese. The quantification of these characteristics was made using a scale of nine points (1-9), where the mark given increased with higher quality.

\subsection{Statistical analysis}

The Statview ${ }^{\circledR}$ v. 4.0 statistical package (Haycock, Roth, Gagnon, Finzer, \& Soper, 1992) was used for statistical treatment of the results by analysis of variance (ANOVA). This test was used to assess overall statistical differences between chemical (and biochemical) data putatively caused by the type of coagulant, the ripening time and the interaction thereof.

\section{Results and discussion}

The aqueous extract obtained from suspended cells of C. calcitrapa, unlike that obtained from the flowers and the leaves of that same plant (Domingos et al., 1992a), did not exhibit milk clotting activity. However, after the renneting process, the curd became slightly softer than that obtained with only chymosin. The presence of said extract did not influence the milk composition of the resulting whey, which was similar in the various experimental runs (results not shown).

The compositional analysis, including the various nitrogen fractions throughout the ripening period, for the experimental cheeses yielded results that are summarized in Table 1. Changes in the moisture contents for all experimental cheeses throughout ripening were significant at the $1 \%$ level. The percent moisture $(\%, \mathrm{w} / \mathrm{w})$ was, during the ripening period, similar in the various experimental cheeses, and decreased almost linearly with time $(P<0.0001)$. The cheeses manufactured with the plant's extract showed, for each time of maturation, significant differences when compared to cheeses manufactured without plant extract $(P=0.0002)$, which exhibited the lowest moisture contents. Higher values were obtained in cheeses manufactured with the higher extract concentration. The presence of the plant extract led to a slower loss of water, but by the end of maturation all cheeses had loosed ca. $12 \%$ of their initial weight.

Changes in the fat and protein contents of all experimental cheeses by $0,7,14$ and $28 \mathrm{~d}$ of ripening are also shown in Table 1. The fat content (expressed as \% of total solids, TS) and the protein content (also expressed as $\%$ of TS) remained virtually constant throughout time, but the total fat contents were significantly different between the various experimental cheeses $(P=0.0002)$. Losses of fat during manufacture may be claimed to have caused this result, since the fat percent of the cheese milk had been initially standardized.

The $\mathrm{NaCl}$ content (expressed as \% of TS) of the cheeses increased during the first $14 \mathrm{~d}$ of ripening, probably owing to diffusion of $\mathrm{NaCl}$ into, and loss of water by the cheese, and remained relatively constant thereafter.

The $\mathrm{pH}$ at the surface and in the centre of the cheeses decreased, likely as a result of lactic acid production. The lowest values of $\mathrm{pH}$ were attained in cheeses added with the plant extracts, which were significantly different when compared with cheeses manufactured without plant extract (see Table 1).

The WSN/TN ratio has been used by a number of researchers to follow ageing of cheese; the values of WSN/TN increased in all experimental cheeses throughout the ripening period (see Table 1), but no significant differences were observed between cheeses manufactured with or without the plant extract $(P=0.0349)$. The TCASN/TN ratio has been used to evaluate the effect of lactic acid bacteria in the formation of soluble $\mathrm{N}$ compounds in cheese (Furtado \& Partridge, 1988); this fraction contains small peptides of between 2 and 20 amino acid residues. The value of the TCASN/TN ratio of the cheeses increased throughout ripening (see Table 1), but again the differences were not significant between the various experimental cheeses $(P=0.4459)$. The free amino acid index, represented by the PTASN/TN ratio (Sousa \& Malcata, 1997a,b; Jarret, Aston, \& Dulley, 1982; Aston et al., 1983), increased significantly with ripening time for every experimental cheese (see Table 1). However, in cheeses that were not produced with the plant extract that ratio was higher (at the $1 \%$ level of significance) than in cheeses produced with that extract $(P=0.0003)$. Similar results were reported by Sousa and Malcata (1997b) in cheeses manufactured from ewes' raw milk. According to those authors, the breakdown of caseins by proteinases presented in the flowers' extract of C. cardunculus into high molecular weight peptides did not extend further onto lower molecular weight peptides and free amino acids.

Urea-PAGE electrophoretograms of water-insoluble nitrogen (WISN) exhibited one group with lower mobility than $\alpha_{\mathrm{s} 1}$-casein; this group was accounted for by $\beta$-casein, which undergoes a more limited hydrolysis than $\alpha_{\mathrm{s} 1}$-casein (see Fig. 1a-c). The percentage of degradation of $\beta$-casein was rather low for all experimental cheeses, 
Table 1

Changes in composition and ripening indices, throughout the ripening period, in pasteurized cow milk cheeses coagulated with chymosin, and not added (a) or added with the extract of Centaurea calcitrapa at (b) $0.61 \mathrm{mg}$ total protein $\mathrm{mL}^{-1}$ or (c) $1.22 \mathrm{mg}$ total protein $\mathrm{mL}^{-1 \mathrm{a}}$

\begin{tabular}{|c|c|c|c|c|c|}
\hline \multirow[t]{2}{*}{ Parameter } & \multirow[t]{2}{*}{ Cheese type } & \multicolumn{4}{|c|}{ Ripening time (d) } \\
\hline & & 0 & 7 & 14 & 28 \\
\hline Moisture $(\% \mathrm{w} / \mathrm{w})^{\mathrm{b}}$ & $\begin{array}{l}\mathrm{a} \\
\mathrm{b} \\
\mathrm{c}\end{array}$ & $\begin{array}{l}51.98 \pm 0.30 \\
53.33 \pm 0.43 \\
56.57 \pm 0.33\end{array}$ & $\begin{array}{l}47.72 \pm 1.03 \\
51.56 \pm 0.91 \\
54.14 \pm 0.28\end{array}$ & $\begin{array}{l}47.46 \pm 1.58 \\
48.78 \pm 0.38 \\
52.05 \pm 0.93\end{array}$ & $\begin{array}{l}45.68 \pm 0.58 \\
46.57 \pm 0.36 \\
49.62 \pm 0.17\end{array}$ \\
\hline Fat $\left(\% \mathrm{w} / \mathrm{w}_{\mathrm{TS}}\right)^{\mathrm{b}}$ & $\begin{array}{l}\mathrm{a} \\
\mathrm{b} \\
\mathrm{c}\end{array}$ & $\begin{array}{l}54.92 \pm 0.37 \\
56.24 \pm 1.08 \\
51.81 \pm 0.37\end{array}$ & $\begin{array}{l}54.06 \pm 1.11 \\
54.70 \pm 0.02 \\
53.70 \pm 0.87\end{array}$ & $\begin{array}{l}54.71 \pm 0.55 \\
58.07 \pm 0.78 \\
52.93 \pm 0.85\end{array}$ & $\begin{array}{l}54.31 \pm 0.83 \\
56.61 \pm 0.52 \\
53.22 \pm 0.37\end{array}$ \\
\hline Protein $\left(\% \mathrm{w} / \mathrm{w}_{\mathrm{TS}}\right)$ & $\begin{array}{l}\mathrm{a} \\
\mathrm{b} \\
\mathrm{c}\end{array}$ & $\begin{array}{l}37.41 \pm 1.15 \\
34.60 \pm 0.95 \\
37.58 \pm 1.56\end{array}$ & $\begin{array}{l}35.80 \pm 0.31 \\
33.24 \pm 1.26 \\
38.16 \pm 2.77\end{array}$ & $\begin{array}{l}36.01 \pm 0.46 \\
33.95 \pm 0.33 \\
37.18 \pm 1.12\end{array}$ & $\begin{array}{l}35.96 \pm 0.55 \\
35.34 \pm 0.88 \\
36.42 \pm 0.96\end{array}$ \\
\hline $\mathrm{NaCl}\left(\% \mathrm{w} / \mathrm{w}_{\mathrm{TS}}\right)$ & $\begin{array}{l}\mathrm{a} \\
\mathrm{b} \\
\mathrm{c}\end{array}$ & $\begin{array}{l}2.89 \pm 0.28 \\
2.61 \pm 0.08 \\
2.92 \pm 0.02\end{array}$ & $\begin{array}{l}3.90 \pm 0.07 \\
3.93 \pm 0.17 \\
4.68 \pm 0.01\end{array}$ & $\begin{array}{l}5.23 \pm 1.27 \\
4.57 \pm 0.03 \\
4.98 \pm 0.19\end{array}$ & $\begin{array}{l}4.93 \pm 0.04 \\
5.11 \pm 0.02 \\
5.02 \pm 0.18\end{array}$ \\
\hline $\mathrm{pH}$ at centre ${ }^{\mathrm{b}}$ & $\begin{array}{l}\mathrm{a} \\
\mathrm{b} \\
\mathrm{c}\end{array}$ & $\begin{array}{l}5.69 \pm 0.03 \\
5.57 \pm 0.01 \\
5.43 \pm 0.02\end{array}$ & $\begin{array}{l}5.57 \pm 0.01 \\
5.51 \pm 0.02 \\
5.45 \pm 0.01\end{array}$ & $\begin{array}{l}5.43 \pm 0.10 \\
5.37 \pm 0.02 \\
5.24 \pm 0.01\end{array}$ & $\begin{array}{l}5.36 \pm 0.01 \\
5.40 \pm 0.05 \\
5.26 \pm 0.02\end{array}$ \\
\hline $\mathrm{pH}$ at surface ${ }^{\mathrm{b}}$ & $\begin{array}{l}\mathrm{a} \\
\mathrm{b} \\
\mathrm{c}\end{array}$ & $\begin{array}{l}6.10 \pm 0.02 \\
5.92 \pm 0.02 \\
5.75 \pm 0.01\end{array}$ & $\begin{array}{l}5.85 \pm 0.01 \\
5.64 \pm 0.04 \\
5.65 \pm 0.04\end{array}$ & $\begin{array}{l}5.61 \pm 0.04 \\
5.61 \pm 0.02 \\
5.48 \pm 0.02\end{array}$ & $\begin{array}{l}5.47 \pm 0.02 \\
5.55 \pm 0.03 \\
5.39 \pm 0.01\end{array}$ \\
\hline $\mathrm{WSN}\left(\% \mathrm{w} / \mathrm{w}_{\mathrm{TN}}\right)$ & $\begin{array}{l}\mathrm{a} \\
\mathrm{b} \\
\mathrm{c}\end{array}$ & $\begin{array}{l}3.50 \pm 0.08 \\
4.31 \pm 0.06 \\
4.31 \pm 0.16\end{array}$ & $\begin{array}{l}6.23 \pm 0.15 \\
7.29 \pm 0.46 \\
7.73 \pm 0.58\end{array}$ & $\begin{array}{r}8.72 \pm 0.65 \\
10.07 \pm 0.33 \\
10.34 \pm 0.16\end{array}$ & $\begin{array}{l}11.97 \pm 0.66 \\
13.15 \pm 0.35 \\
13.57 \pm 0.69\end{array}$ \\
\hline $\operatorname{TCASN}\left(\% \mathrm{w} / \mathrm{w}_{\mathrm{TN}}\right)$ & $\begin{array}{l}\mathrm{a} \\
\mathrm{b} \\
\mathrm{c}\end{array}$ & $\begin{array}{l}1.13 \pm 0.12 \\
1.39 \pm 0.02 \\
1.67 \pm 0.04\end{array}$ & $\begin{array}{l}2.68 \pm 0.20 \\
3.16 \pm 0.16 \\
3.29 \pm 0.38\end{array}$ & $\begin{array}{l}3.96 \pm 0.47 \\
4.36 \pm 0.12 \\
4.82 \pm 0.16\end{array}$ & $\begin{array}{l}5.97 \pm 0.16 \\
6.13 \pm 0.12 \\
6.68 \pm 0.19\end{array}$ \\
\hline $\operatorname{PTASN}\left(\% \mathrm{w} / \mathrm{w}_{\mathrm{TN}}\right)^{\mathrm{b}}$ & $\begin{array}{l}a \\
b \\
c\end{array}$ & $\begin{array}{l}0.35 \pm 0.02 \\
0.40 \pm 0.12 \\
0.33 \pm 0.02\end{array}$ & $\begin{array}{l}0.54 \pm 0.08 \\
0.49 \pm 0.14 \\
0.44 \pm 0.06\end{array}$ & $\begin{array}{l}0.78 \pm 0.09 \\
0.64 \pm 0.11 \\
0.70 \pm 0.02\end{array}$ & $\begin{array}{l}1.46 \pm 0.20 \\
0.98 \pm 0.08 \\
1.06 \pm 0.02\end{array}$ \\
\hline
\end{tabular}

${ }^{a}$ Results shown are mean \pm standard deviation (of duplicates from two cheeses).

${ }^{\mathrm{b}}$ Significant difference between the $\mathrm{a}, \mathrm{b}$ and $\mathrm{c}$ cheese types throughout ripening time $(P<0.01)$.

and not significantly different between them. The product of such degradation process is probably $\beta$-I-casein (Gripon, Desmazeaud, Le Bars, \& Bergére, 1975), which should, in our data, be represented by band A (see Fig. 1a-c). Several bands in Fig. 1 with lower electrophoretic mobility account for $\gamma_{1}-, \gamma_{2}$ - and $\gamma_{3}$ casein; their relative positions are identical to those in Cheddar and Gouda cheeses (Creamer, 1975). These bands increased in density gradually throughout maturation, especially in cheeses produced with the plant extract. Milk protease is the enzyme most likely responsible for release of $\gamma$-caseins from $\beta$-casein in fresh bovine milk, but it is possible that microbial enzymes (Creamer, 1975) and enzymes contributed by the plant coagulant (Fernández del Pozo, Gaya, Medina, Rodriguez-Marín $\&$ Nuñez, 1988) played also a role in the formation of those peptides in cheese. $\alpha_{\mathrm{s} 1}$-Casein was degraded more extensively than $\beta$-casein. Results reported by Tavaria et al. (1997), using bovine and ovine caseinate hydrolysed by extracts of flowers of $C$. calcitrapa, indicated that $\alpha_{\mathrm{s} 1}$-caseins were degraded to a higher extent than $\beta$ caseins. Furthermore, Sousa and Malcata (1997a,b), when analysing cheeses manufactured with raw ewes' milk and extracts of flowers of $C$. cardunculus, found that $\beta$-casein was less degraded than $\alpha_{\mathrm{s} 1}$-casein.

Hydrolysis of $\alpha_{\mathrm{s} 1}$-casein leads to appearance and accumulation of one band (termed band B), the mobility of which is similar to that of $\alpha_{\mathrm{s} 1}$-I-casein, which is claimed (Whyte, 1995) to be a result of the breakdown of $\alpha_{\mathrm{s} 1}$ casein by chymosin or, alternatively, by proteinases of $C$. cardunculus (Sousa \& Malcata, 1997a). The extent of degradation of $\alpha_{\mathrm{s} 1}$-casein was higher, especially by $7 \mathrm{~d}$ of ripening, in cheeses produced with the extract of $C$. calcitrapa $(14.9 \%$ vs. $37.3 \%$ of degradation for cheeses produced with 0.61 and $1.22 \mathrm{mg}$ total protein $\mathrm{mL}^{-1}$, respectively, and $10.8 \%$ in plant additive-free cheeses). In 
a

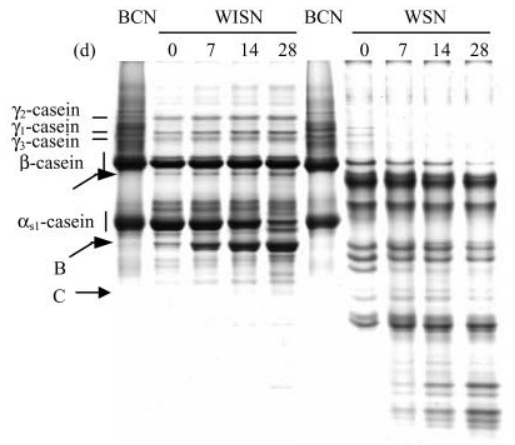

b

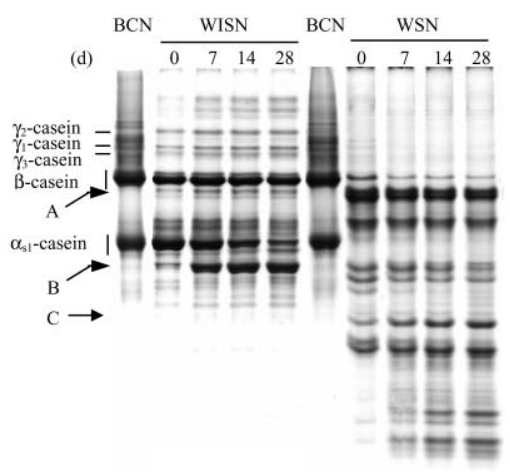

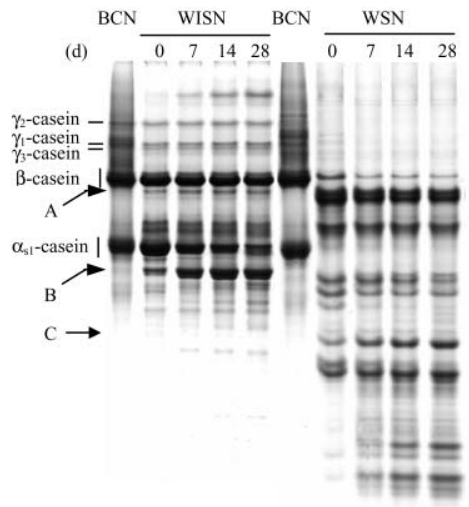

Fig. 1. Urea-PAGE electrophoretograms of the water-insoluble nitrogen fraction (WISN) and the water-soluble nitrogen fraction (WSN) of the cheeses coagulated with chymosin, and not added (a) or added with the extract of Centaurea calcitrapa at (b) $0.61 \mathrm{mg}$ total protein mL $\mathrm{mL}^{-1}$ or (c) $1.22 \mathrm{mg}$ total protein $\mathrm{mL}^{-1}$, by $0,7,14$ and $28 \mathrm{~d}$ of ripening. Bovine caseinate $(\mathrm{BCN})$ was included as reference.

Table 2

Values of organoleptic assessment by $28 \mathrm{~d}$ of ripening of experimental cheeses manufactured with chymosin, and not added (a) or added with the extract of Centaurea calcitrapa at (b) $0.61 \mathrm{mg}$ total protein $\mathrm{mL}^{-1}$ or (c) $1.22 \mathrm{mg}$ total protein $\mathrm{mL}^{-1 \mathrm{a}}$

\begin{tabular}{|c|c|c|c|c|c|c|}
\hline \multirow[t]{2}{*}{ Type of cheese } & \multicolumn{6}{|c|}{ Sensory parameters (scores scale: $1-9$ ) } \\
\hline & Shape & Rind & Colour & Texture & Flavour & Aroma \\
\hline $\mathrm{a}$ & $6.0 \pm 1.8$ & $7.4 \pm 1.2$ & $7.2 \pm 1.0$ & $6.5 \pm 1.2$ & $5.4 \pm 0.9$ & $5.8 \pm 0.7$ \\
\hline $\mathrm{b}$ & $6.3 \pm 1.4$ & $7.5 \pm 1.1$ & $7.1 \pm 1.0$ & $5.3 \pm 1.1$ & $3.1 \pm 0.9$ & $3.4 \pm 1.2$ \\
\hline $\mathrm{c}$ & $6.3 \pm 1.4$ & $7.5 \pm 1.1$ & $7.1 \pm 1.0$ & $5.2 \pm 1.2$ & $2.9 \pm 1.1$ & $3.3 \pm 1.0$ \\
\hline
\end{tabular}

${ }^{\mathrm{a}}$ Results shown are mean \pm standard deviation (of replicates consubstantiated in 6 panelists).

the remaining ripening period, the differences were not significant at all $(72.9$ and $73.8 \%$ for cheeses added with 0.61 and $1.22 \mathrm{mg}$ total protein $\mathrm{mL}^{-1}$, respectively, and $73.3 \%$ in plant additive-free cheeses). The electrophoretograms of WSN (see Fig. 1a-c) exhibited a large number of bands throughout ripening, with several differences between the various experimental cheeses; one band with higher eletrophoretic mobility than $\alpha_{\mathrm{s} 1}$-casein, termed band $\mathrm{C}$, was produced from the very beginning of ripening in all cheeses, but was more intense in cheeses produced with the plant extract. The overall shape (form, rind, colour and texture) of the experimental cheeses was rated as quite satisfactory by the taste panel (all scores were indeed above 5 in the 1-9 scale) (Table 2). However, the cheeses manufactured with plant extract developed a more bitter and somewhat unpleasant flavour than those without. For the development of acceptable flavours, a balanced breakdown of the curd protein (i.e. caseins) into small peptides and free amino acids is necessary (Visser, 1993). Van den Berg (1992) has reported that most preparations from plants are excessively proteolytic and hence promote bitterness. Therefore, since the only difference in the manufacture process of the cheeses was the presence or absence of $C$. calcitrapa extract, one may conclude that said extract is directly responsible for such slight off-flavour detected.

\section{Conclusions}

The addition of an aqueous extract of $C$. calcitrapa early during cheesemaking produced a significant effect (at the $1 \%$ level of significance) upon cheese composition in terms of moisture and fat contents. The ripening index was not influenced by said plant extract, so a weak proteolytic activity can be ascribed to it. However, the levels of PTASN/TN throughout ripening were significantly lower in cheeses produced with that plant extract than in cheeses manufactured with only chymosin. The electrophoretic profiles indicated a higher percent degradation of $\alpha_{\mathrm{s} 1}$-casein than $\beta$-casein, which was not affected by addition of the $C$. calcitrapa extract. The sensorial analysis of the cheeses containing the plant additive revealed somewhat more bitter flavour than of those produced without it. The extract from C. calcitrapa should be carefully evaluated as a suitable proteolytic additive towards improvement of the Castelões cheesemaking process, namely via combination with a commercial 
stronger starter (or non-starter) culture to assure breakdown of the extra (bitter) peptides thus generated.

\section{Acknowledgements}

The company Lactogal, S.A. is hereby gratefully acknowledged for its technical cooperation in laying out the experimental program. Financial support for this research effort was through PAMAF project 3010 - "Avaliação da aplicabilidade de proteases de Centaurea calcitrapa no desenvolvimento de produtos lácteos", administered by Instituto Nacional de Investigação Agrária (INIA, Portugal).

\section{References}

Andrews, A. T. J. (1983). Proteinases in normal bovine milk and their action on caseins. Journal of Dairy Research, 50, 45-55.

Anon. (1975). Fromages. Détermination de la teneur en matière grasse. Norme Internationale ISO No 3433, Nederlands NormalisatieInstitut, Delft, The Netherlands.

Aston, J. W., Durward, I. G., \& Dulley, J. R. (1983). Proteolysis and flavour development in Cheddar cheese. Australian Journal of Dairy Technology, 38, 55-59.

Blakesley, R. W., \& Boezi, J. A. (1977). A new staining technique for proteins in polyacrylamide gels using Coomassie Brillant Blue G250. Analytical Biochemistry, 82, 55-585.

Bradford, M. (1976). A rapid and sensitive method for the quantitation of microgram quantities of protein utilising the principle of proteindye binding. Analytical Biochemistry, 72, 248-254.

Cordeiro, M., Jakob, E., Puhan, Z., Pais, M. S., \& Brodelius, P. E. (1992). Milk clotting and proteolytic activities of purified cynarases from Cynara cardunculus - a comparison to chymosin. Milchwissenschaft, 47, 683-687.

Creamer, L. K. (1975). $\beta$-Casein degradation in Gouda and Cheddar cheese. Journal of Dairy Science, 58, 287-292.

Domingos, A., Clemente, A., \& Pais, M. S. (1992a). Studies on proteases with milk clotting activity from Centaurea calcitrapa. Mededelingen van de Faculteit Landbouwwetenschappen Rijksuniversiteit Gent, 57, 1909-1910.

Domingos, A., Miguel, G., Clemente, A., \& Pais, M. S. (1992b). Production of clotting enzymes by in vivo plants and cell suspension cultures of Centaurea calcitrapa (Compositae). In Duarte, M. C., $\&$ Cabrol, J. C. (Eds.), Proceedings of recent advances in industrial applications of biotechnology (pp. 511-513). NATO-ASI series. Dordrecht: Kluwer.

Faro, C. (1991). Purification and physicochemical characterization of a protease from Cynara cardunculus L. Ph.D. thesis, University of Coimbra, Coimbra, Portugal.

Fernández del Pozo, B., Gaya, B., Medina, M., Rodriguez-Marín, M. A., \& Nuñez, M. (1988). Changes in chemical and rheological characteristics of La Serena ewe's milk cheese during ripening. Journal of Dairy Research, 55, 457-464.

Fox, P. F. (1989). Proteolysis during cheese manufacture and ripening. Journal of Dairy Science, 72, 1379-1400.
Franco, J. A. (1984). Nova Flora de Portugal (Continente e Açores), vol. II. Lisboa, Portugal: Veilo.

Furtado, M. M., \& Partridge, J. A. (1988). Characterization of nitrogen fractions during ripening of a soft cheese made from ultrafiltration retentates. Journal of Dairy Science, 71, 2877-2885.

Gripon, J. C., Desmazeaud, M. J., Le Bars, D., \& Bergére, J. L. (1975). Role of microorganisms and their enzymes in cheese ripening. II. Effect of commercial rennet. Le Lait, 55, 502-513.

Haycock, K., Roth, J., Gagnon, J., Finzer, W. F., \& Soper, C. (1992). Statview v. 4.0: The ultimate integrated data analysis and presentation system. Berkeley, CA, USA: Abacus concepts.

Heimgartner, U., Pietrzak, M., Geertsen, R., Brodelius, P., Silva Figueiredo, A. C., \& Pais, M. S. (1990). Purification and partial characterization of milk clotting proteases from flowers of Cynara cardunculus. Phytochemistry, 29, 1405-1410.

Jarret, W. D., Aston, J. W., \& Dulley, J. R. (1982). A simple method for estimating free amino acids in Cheddar cheese. Australian Journal of Dairy Technology, 37, 55-58.

Kuchroo, C. N., \& Fox, P. F. (1982). Soluble nitrogen in Cheddar cheese: comparison of extraction procedures. Milchwissenschaft, 37, 331-335.

Kosikowski, F. V. (1982). Cheese and fermented milk foods. Brooktondale, New York, USA: Kosikowski and Associates.

Macedo, I. Q. (1993). Caseinolytic specificity of a protease from the cardoon Cynara cardunculus L. Ph.D. thesis, University of Coimbra, Coimbra, Portugal.

Pires, E., Faro, C., Macedo, I., Esteves, C., Morgado, J., Veríssimo, P., Pereira, D., \& Gomes, D. (1994). Flor do cardo versus quimosina no fabrico de queijos artesanais. Química Alimentar, 54, 66-68.

Quer, P. (1981). Plantas Medicinales. Madrid, Spain: Editorial Labor.

Sá, F. V., \& Barbosa, M. (1972). Cheese making with a vegetable rennet from cardoon (Cynara cardunculus). Journal of Dairy Research, 39, 335-343.

Shalabi, S. I., \& Fox, P. F. (1987). Electrophoretic analysis of cheese: comparison of methods. Irish Journal of Food Science and Techno$\log y, 11,135-151$.

Sousa, M. J., \& Malcata, F. X. (1997a). Comparison of plant and animal rennets in terms of microbiological, chemical and biochemical characteristics of ovine cheese. Journal of Agriculture and Food Chemistry, 45, 74-81.

Sousa, M. J., \& Malcata, F. X. (1997b). Comparative biochemical evolution during ripening of bovine, ovine, and caprine cheeses manufactured with extracts of flowers of Cynara cardunculus. Zeitschrift für Lebensmittel Untersuchung und Forschung, 205, 97-103.

Tavaria, F. K., Sousa, M. J., Domingos, A., Malcata, F. X., Brodelius, P., Clemente, A., \& Pais, M. S. (1997). Degradation of caseins from milk of different species by extracts of Centaurea calcitrapa. Journal of Agriculture and Food Chemistry, 45, 3760-3765.

Twining, S. S. (1984). Fluorescein isothiocyanate-labeled casein assay for proteolytic enzymes. Analytical Biochemistry, 143, 30-34.

van den Berg, R. (1992). Fermentation-produced chymosin, technological aspects of its use for cheesemaking. International Dairy Federation Bulletin, 269, 13-17.

Visser, S. (1993). Proteolytic enzymes and their relation to cheese ripening and flavour: an overview. Journal of Dairy Science, 76, 329-350.

Whyte, N. H. (1995). Proteolysis of bovine and ovine caseins by lamb and calf chymosin. M.Sc. thesis, National University of Ireland, Cork, Ireland. 